\title{
Agrifood value chain assessment in developing countries: a case of Indonesia's cashew sector
}

\author{
Dwi Ratna Hidayati ${ }^{1 *}$, Elena Garnevska ${ }^{2}$, and Paul Childerhouse ${ }^{3}$ \\ ${ }^{1}$ School of Agriculture and Environment, Massey University, New Zealand and Agribusiness \\ Department of University of Trunojoyo Madura, Indonesia \\ ${ }^{2}$ School of Agriculture and Environment, Massey University, New Zealand \\ ${ }^{3}$ School of Food and Advanced Technology, Massey University, New Zealand
}

\begin{abstract}
A value chain approach is increasingly used in the agrifood sector to help respond to the globalised food system. However, the agrifood value chain in many developing countries faces additional challenges to address any changes regarding the prevalence of smallholder players. Meanwhile, value chain studies are still limited in many developing countries, such as in Indonesia. Therefore, this paper aims to assess agrifood value chain in a developing country context. A qualitative methodology was applied in Indonesia's cashew sector, specifically in the Sumenep Regency of Madura Island. A value chain mapping tool was used by focusing on governance (vertical-horizontal coordination and information flow) and value addition (safety, quality, and value orientation). The results showed that value chain mapping is a powerful tool to draw the complex interaction within the dynamics between different value chain actors. The exploration in Indonesia's cashew sector showed that there is a gap in practices between actors in terms of governance and value addition. Therefore, it is recommended that smallholders' governance participation and value adding activities be improved in order to minimize the gap of practises. The potential follow-up research is to address the maturity level of value chain practice to obtain a rigorous improvement route.
\end{abstract}

\section{Introduction}

The agrifood value chain has been increasingly studied within the context of developing countries to help respond to the changes in the global system, especially in terms of globalisation and high-value food standards. Through the value chain lens, all agrifood actors have to cooperate in order to be able to respond to these changes. Value chain studies offer a comprehensive approach because they embrace the whole range of activities to carry out products or services by aiming at either the local, national, or global market [1]. The value chain also highlights the importance of value creation along with the development of interrelationships between activities [2]. However, in many cases, agrifood value chains in developing countries have a challenging characteristic to respond to any changes. The agrifood sector of developing countries is dominated by smallholders [3], who practice

\footnotetext{
* Corresponding author: dhidayat@massey.ac.nz/dwi.hidayati@trunojoyo.ac.id
} 
'traditional social norms' [4] and often involve intermediaries [5,6]. A number of studies have shown that many smallholders would be characterized by limited capacity in terms of a high-value requirement such as low quality, low production, poor education, limited market access, and limited market information [7,8,9,10].

Value chain assessment is an important early-stage identification to assist developing countries actors in evaluating their practices. The identification of the overall practice will also pay attention to the sector characteristics. In general, the agrifood sector is characterized by a combination of sensitive features and product utilization which challenges value creation. It is because this sector has a high reliance on environmental condition quality [4], [11] and salient quality dimension due to perishability feature [12]. Therefore, agrifood value chain assessment would depend on how the players interact to create the value that is related to commodity feature, utilization, and technology. Several studies have also shown that the critical component of agrifood value chain includes governance $[8,13,14]$ and value-addition $[12,15]$. Agrifood governance focuses on market dynamics to arrange the chain rule [16]. Meanwhile, value addition is concerned with the way each stage contributes to the product's value $[12,17]$.

Indonesia is an agriculture-based developing country, which plays an important role in global trade. Agrifood products from Indonesia, and which are sold globally, will be required to adjust to the global food system, particularly in terms of quality and safety standards. One of the potential high-value foods supplied by Indonesia in the global market is cashew nuts. Indonesia is a notable cashew nut producer [18-20] and about $70 \%$ of cashew nuts have been exported to Vietnam and India for processing [21]. In 2014, the Ministry of Trade proposed a ban on raw cashew nut exports, however, no relevant regulation was proposed. Instead, Indonesia's Government had listed cashew nuts as one of the strategic commodities in 2016 by regulation Number 44, which allowed capital investment in both planting and processing [22]. By focusing on activities that capture more value, the cashew sector in Indonesia will have a greater opportunity to supply a higher value market. However, value chain studies are still limited in Indonesia. Most of the available studies focus on enhancing cashew production $[23,24]$, quality [25], and competitiveness [26,27].

Therefore, this paper aims to assess the cashew nuts' value chain in Indonesia. This study will fill the gap of value chain literature in Indonesia and help practitioners, along with policymakers, to better understand Indonesia's cashew sector and how to respond to the challenges in global system. Notably, this result will contribute to the growth of knowledge on how a developing country can be more effective in responding to the globalised food system.

\section{Theoretical framework}

A value chain concept is an approach that evolves and develops from various disciplines. Porter has a broad influence on value chain knowledge development by introducing the competitive advantage. A competitive advantage places 'competition' as the core success of the business and further defines it as the value-added interlink activities which consist of primary and supporting operations from the sourcing stage up to the end consumer stage [2831]. However, the competition nowadays has shifted from between individual firms into the entire networking governance [32]. This new paradigm further affects chain parties to cooperate tightly in creating value. Thus, the value chain has become a critical tool that, not only identifies the potential stage to increase customer value and to reduce costs, but also understands business relationships with stakeholders [33].

One of the strategic tools that assesses and evaluates the agrifood system practice for transformation purposes, is value chain mapping. The agrifood value chain should be perceived as a system [15]; therefore, value chain mapping is delineated to collect an initial 
overview of value chain key aspects $[4,13]$. This method is suitable for transformation because of employing a significant platform that includes a specific agenda on the process, actors, and value-added [34]. The current practice should be scanned to identify both actors and system that urgently require improvement. In this paper, governance and value addition are highlighted as two critical dimensions in agrifood value chain mapping. These dimensions describe the key activities in a value chain.

Governance represents a complex interaction of different actors in the value chain, such as transactions within information $[3,35]$ and the control of the value chain through power or institutions [13]. Therefore, governance generally emphasizes three imperative dimensions: vertical coordination, horizontal coordination, and information flow. Vertical coordination includes informal coordination, bilateral contract, or network governance [36], while horizontal coordination is often interpreted as a collaboration between producers, such as farmers' group and cooperatives [37]. Finally, governance also contains information flow [16], where an efficient information flow could improve performance and further lead to traceability profit [38].

Value-addition represents each stage of the chain's activity which contribute to adding a product's value [28,30]. The series of agrifood value-adding activities include farm production, processing, and delivery to consumers $[39,40]$. Three key elements in value addition can be specified as quality, safety, and value orientation. In adding these values, value orientation plays an important role.[12,40,41] Value-addition may aim to keep the product fresh and transfer fast, and then the processed food transform the raw materials into various processed activities to result in consumed-value [12,40,41]. In addition to this, the value-added should involve quality and safety, which increasingly count as essential elements in the agrifood product [42]. These two powerful dimensions of VC will be used to assess the value chain of cashew nuts in Indonesia, which can be further illustrated in the following framework.

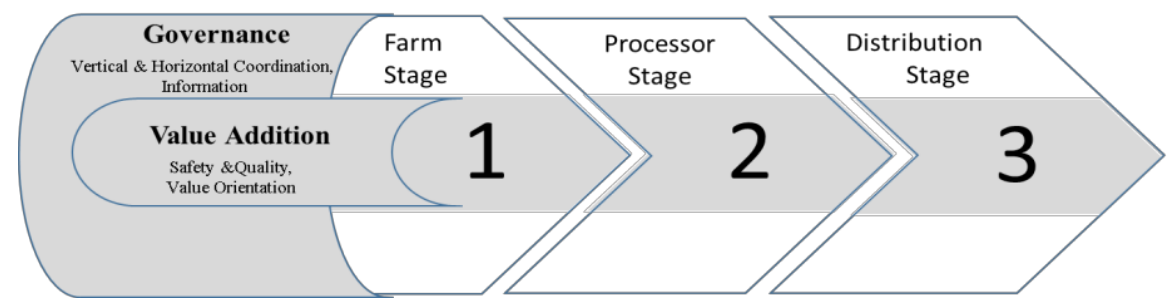

Fig. 1. Agrifood Value Chain Mapping Framework (Source: Author)

\section{Methodology}

This study was conducted on Madura Island, which is one of the central cashew producers in Indonesia [24], from January up to early February 2020. The cashew area on the Island is approximately 30,167 ha of, with productivity in average is around 0.76 ton per ha. Furthermore, the 'Cashew Belt' program was implemented in this area through intensification of around 2,660 ha in 2014 [43]. Because of its proximity to Surabaya's transnational port facilities, this Island has a strategic location for trade [44]. Among four regencies in the Island, Sumenep Regency was chosen as the case study area, because it has been the leading cashew producer [45].

The research used qualitative methodology. Primary data was collected by using semistructured interviews with key players of the cashew nuts value chain. The questionnaire was developed by using indicators on governance and value addition. In total, 25 interviews were held with farmers, farmer groups, intermediaries, processors, exporter and government 
officers (Extension workers, Cooperative and Small Medium Enterprise Agency, and Trade and Industrial Agency). The data collection process used a combination of snowball and purposive sampling. The snowball sampling was specifically used to gain information from the value chain actors (farmers up to exporters). Meanwhile, purposive sampling was used to acquire data from the government officers' respondent. The respondents were asked to make comments based on their experience, express their thoughts, and justify their remarks. Following that, the data were assessed using spiral analysis, which involves categories and sub-categories' classification in an iterative way.

\section{Result and discussion}

Overall, the findings have generated evidence that smallholder farmers in a developing country make a considerable contribution to global market supply. To present the findings, the value chain assessment in this paper is divided into two parts. It started with a mapping of the cashew nuts value chain in the study area, illustrated in Figure 2. The second part analysed and discussed the complex interaction between value chain actors (in terms of governance and value addition), as shown in Table 1.

The cashew nuts value chain in the study area is export-oriented in the form of raw material. Around $75 \%$ of cashew products (dry in shell nuts quality) is exported mainly to India and Vietnam. Meanwhile, the remaining cashew nuts (approximately 25\%) are marketed at domestic market in the form of processed products.

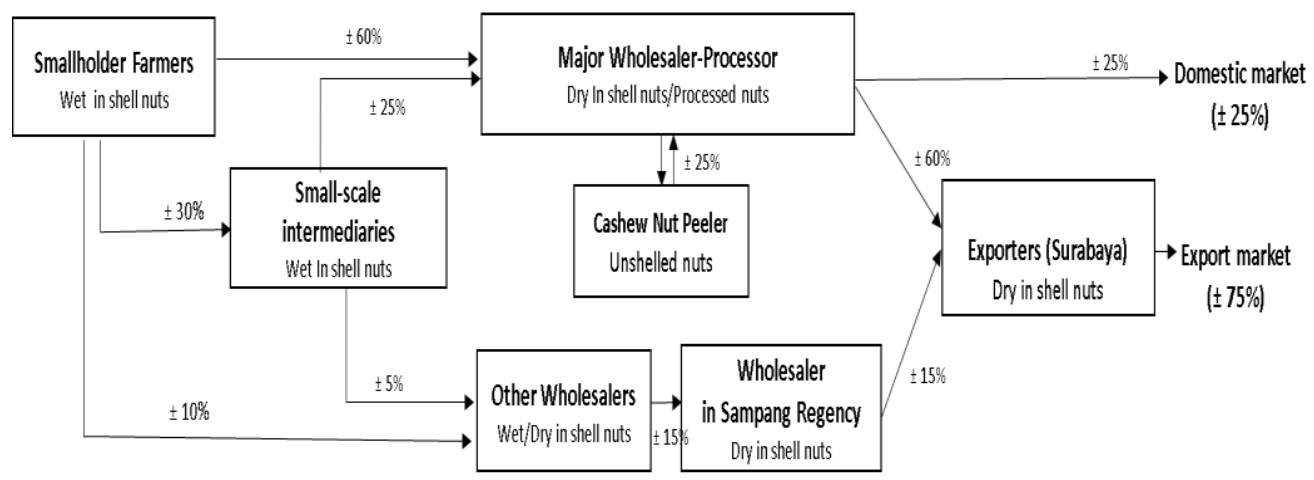

Note:

Wet in shell nuts: raw fresh in shell nuts after harvesting.

Dry in shell nuts: raw wet in shell nuts that have been through drying process for around 3-4 days of sun exposure.

Processed nuts: raw unshelled nuts and/or further processing activities to create ready consumption product

Fig. 2. Cashew Nuts Value Chain in Sumenep Regency of Indonesia

The cashew value chain involves various actors at different stages. The chain starts with a large number of smallholder farmers. Based on the interview, cashew farm ownership is generally an inherited family business over generations. With an average farm size of 0.3-0.4 ha (less than 100 cashew trees), smallholders practiced cashew farming as berms/hedgerow cultivation using minimum input and diversified farms with seasonal plants such as corn or paddy. It is because many smallholders used cashew cultivation as investment plants that generate annual income. Smallholders would likely sell cashew nuts in 'wet in shell' form. After harvesting, they would sell most of their cashew nuts either to intermediaries or the wholesalers. In many cases, small-scale intermediaries would buy at the cashew farm site or standby in the marketplace. However, they gathered cashew nuts from smallholders on an irregular basis and with varying degree of quantity and quality. After that, they would sell 
cashew nuts to wholesalers. At the wholesaler stage, the results revealed that there is a main wholesaler and many other small-scale wholesalers. The main wholesaler plays three critical roles: controlling the majority of cashew nuts' collection, processing cashew nuts into ready for consumption product, and supplying exporters. Meanwhile, other wholesalers focus on gathering cashew nuts and selling to other powerful wholesalers in another Regency (i.e. Sampang). Despite the differences, both types of wholesalers would sell the majority of cashew products in the form of 'dry in shell nuts' to the exporters.

The exporters can be classified as national and global exporters. The global exporters are mainly from Vietnam and India. Meanwhile, national exporters are varied. Some exporters may have offices and regularly operate by exporting various products other than cashew products. Meanwhile, other exporters may not have an official site and only operate during cashew harvesting season. One of the leading exporters in Indonesia is a pioneer firm in the cashew sector (since 1975). This firm focuses on exporting both raw materials and processed products to global markets (i.e. India, Vietnam, China, USA, Europe). To further clarify the cashew value chain operation in terms of governance and value addition, the following table summarizes the key actors' activities.

Table 1 presents the value chain assessment of cashew nuts sector based on governance and value addition dimension. In general, the assessment results show a gap of practices between different value chain stages in both dimensions. The gap practices happened mostly because of a lack of integration [46].

In governance, the vertical coordination assessment indicated that smallholders have less coordination compared to other players. Most of the transactions at the smallholder's stage are short-term, spot transaction-based, price-based and without negotiation. They also rely on small-scale intermediaries and major wholesalers to market cashew nuts. Meanwhile, the contractual relationship is built between major wholesaler and exporters. In fact, this result has commonly happened in developing countries [47]. Agrifood value chain actor relationships in developing countries mostly rely on an informal networking system, in which the role could be varied and not confined to one channel [3]. However, the control of a value chain can be seen [48]. The exporters often prefer a contractual relationship formally with the key supplier[3,47]. Additionally, horizontal coordination provided less support in terms of market-related development to smallholders. The results showed that there are some farmer groups that are helping farmers to apply for government support, such as seed and input subsidies. Despite the farmer group existence, many farmers work individually in their cashew production and marketing. In fact, Producer Organisation (PO) involvement is critical to support smallholders [49].

The information flow generally showed an asymmetrical workflow. Smallholders received less information. This is similar to another study which mentioned that although the traditional wholesaler activities are gathering, grading, and sorting due to capability in differentiating product based on basic observable functions such as size and colour, they do not play a role in terms of information [50]. Hence, by having less information, farmers could lose the selling opportunity and be limited for upgrading to the highest value [14]. For instance, an opportunity to set standards, which is an essential element in the cashew sector[51]. 
Table 1. Cashew Nuts Value Chain Assessment in Sumenep Regency, Indonesia

\begin{tabular}{|c|c|c|c|c|c|}
\hline Dimensions & $\begin{array}{c}\text { Smallholder } \\
\text { farmers }\end{array}$ & \begin{tabular}{|c|} 
Small scale \\
intermediaries
\end{tabular} & $\begin{array}{c}\text { Other } \\
\text { wholesellers }\end{array}$ & $\begin{array}{c}\text { Major wholesaller \& } \\
\text { processor }\end{array}$ & Exporters \\
\hline \multicolumn{6}{|l|}{ Governance } \\
\hline $\begin{array}{l}\text { 1)Vertical } \\
\text { Coordination }\end{array}$ & $\begin{array}{c}\text { - Transaction- } \\
\text { based } \\
\text { - Short term } \\
\text { transaction } \\
\text { - Price-based } \\
\text { - Standard } \\
\text { justification } \\
\text { by buyer }\end{array}$ & $\begin{array}{c}\text { - Transaction- } \\
\text { based } \\
\text { - Short term } \\
\text { transaction } \\
\text { - Price-based } \\
\text { - Standard } \\
\text { justification } \\
\text { by buyer }\end{array}$ & $\begin{array}{c}\text { - } \begin{array}{c}\text { Transaction- } \\
\text { based }\end{array} \\
\text { - Short term } \\
\text { transaction } \\
\text { - Price-based } \\
\text { - Standard } \\
\text { justification } \\
\text { by buyer }\end{array}$ & $\begin{array}{c}\text { - Transaction-based with } \\
\text { farmers \& bilateral contract } \\
\text { with exporters (but not } \\
\text { always the case). } \\
\text { - Short term transaction with } \\
\text { farmers or intermediaries, \& } \\
\text { periodical term transaction } \\
\text { with exporters. } \\
\text { - Price-based negotiation } \\
\text { with } \\
\text { farmers/intermediaries/other } \\
\text { wholesalers; limited } \\
\text { collaboration-negotiation } \\
\text { with exporters } \\
\text { - Standard quality and } \\
\text { quantity are determined and } \\
\text { tested by exporters }\end{array}$ & \begin{tabular}{|c|} 
- Bilateral contract \\
with major \\
wholesaler \\
- Periodical term \\
transaction \\
between the \\
major wholesaler \\
and exporters \\
- Limited \\
collaboration- \\
negotiation with \\
major wholesaler \\
- Export standard \\
arrangement \\
\end{tabular} \\
\hline $\begin{array}{l}\text { 2) Horizontal } \\
\text { Coordination }\end{array}$ & $\begin{array}{c}\text { Individual } \\
\text { power }\end{array}$ & $\begin{array}{c}\text { Individual } \\
\text { power }\end{array}$ & $\begin{array}{c}\text { Individual } \\
\text { power }\end{array}$ & Individual power & $\begin{array}{l}\text { Individual-firm } \\
\text { power }\end{array}$ \\
\hline 3) Information & $\begin{array}{l}\text { Centralized to } \\
\text { the major } \\
\text { wholesaler } \\
\text { (Price } \\
\text { information) }\end{array}$ & $\begin{array}{l}\text { Centralized to } \\
\text { the major } \\
\text { wholesaler } \\
\text { (Price } \\
\text { information) }\end{array}$ & $\begin{array}{l}\text { Centralized to } \\
\text { the major } \\
\text { wholesaler } \\
\text { (Price } \\
\text { information) }\end{array}$ & $\begin{array}{c}\text { Information gained from } \\
\text { exporters are price, quantity, } \\
\text { and quality (limited to size and } \\
\text { colour }\end{array}$ & $\begin{array}{c}\text { Source of price, } \\
\text { quantity, and quality } \\
\text { information }\end{array}$ \\
\hline \multicolumn{6}{|l|}{ Value Addition } \\
\hline 1) Safety & $\begin{array}{c}\text { Diverse local } \\
\text { variety, organic } \\
\text { product } \\
\text { unintentionally }\end{array}$ & No traceability & No traceability & No traceability & $\begin{array}{c}\text { - Sourcing } \\
\text { contract } \\
\text { document with } \\
\text { major } \\
\text { wholesalers } \\
\text { - Certifications } \\
\text { such as } \\
\text { Phytosanitary is } \\
\text { from quarantine } \\
\text { Agency (source: } \\
\text { national leading } \\
\text { exporter) }\end{array}$ \\
\hline 2) Quality & $\begin{array}{c}\text { Unsegregated } \\
\text { commodity, raw } \\
\text { wet in shelled } \\
\text { nuts }\end{array}$ & $\begin{array}{l}\text { Unsegregated } \\
\text { commodity, } \\
\text { raw wet in } \\
\text { shell nuts/dry } \\
\text { in shelled nuts }\end{array}$ & $\begin{array}{c}\text { Segregated, raw } \\
\text { dry in shelled } \\
\text { nuts }\end{array}$ & $\begin{array}{c}\text { - Segregated raw dry in shell } \\
\text { nuts } \\
\text { - Unsegregated unshelled } \\
\text { cashew nuts } \\
\text { - Cashew nuts for } \\
\text { consumption }\end{array}$ & $\begin{array}{c}\text { - Segregated raw } \\
\text { dry in shelled } \\
\text { nuts (less than } \\
200 \text { cashew nuts } \\
\text { per Kg, } 1 \mathrm{Kg} \\
\text { shelled nuts } \\
\text { equals to } 300 \\
\text { grams unshelled } \\
\text { nuts) } \\
\text { - Certified/branded } \\
\text { product (source: } \\
\text { national leading } \\
\text { exporter) }\end{array}$ \\
\hline $\begin{array}{l}\text { 3) Value } \\
\text { Orientation }\end{array}$ & Raw material & Raw material & Raw material & $\begin{array}{c}\text { - Raw material with more } \\
\text { treatment } \\
\text { - More processed product (up } \\
\text { to ready for consumption } \\
\text { product) }\end{array}$ & $\begin{array}{c}\text { Raw material } \\
\text { (majority) } \\
\text { - Branded } \\
\text { processed } \\
\text { product (source: } \\
\text { national leading } \\
\text { exporter) }\end{array}$ \\
\hline
\end{tabular}


The value addition assessment showed poor practice in most stages (in terms of quality, safety, and value orientation), except for the wholesaler-processor and some exporters. For instance, the quality element shows that smallholders and intermediaries pay less attention to the grade of the products, whereas, wholesalers and exporters were practising grading with certain standards (less than 200 cashew nuts per $\mathrm{Kg}, 1 \mathrm{Kg}$ shelled nuts equals 300 grams unshelled nuts). Moreover, specific to the exporter respondent, this firm certified and brand the cashew products in order to follow the global trade standard. Next, in terms of safety, cashew nuts in the study area are claimed as organic products because of using less input in terms of fertilizer and pesticide. However, it is noted that it was unintentionally produced by smallholders. Without awareness, there is a possibility of different cashew production practices in the future. Finally, the value orientation element shows that all stages (from smallholders up to exporters) generally have raw material trade orientation. This assessment illustrates that Indonesia has typically lacked performance in the cashew nuts' processing industry [27]. The main wholesaler-processor has initiated the processing activities for the domestic market. However, there are more opportunities for market development at the processing level of the cashew sector [52]. While cashew plants are primarily suitable for growth in many developing countries; cashew is high-value food for consumption in many developed countries [53].

\section{Conclusions}

This study aimed to assess agrifood value chain in a developing country, hence, help to identify the current practice in order to respond to the globalised food system. The value chain mapping approach being used was useful to provide a detailed, complex and significant overview of the cashew nut value chain in Indonesia. The focused indicators on governance and value addition in value chain mapping had helped to do both identifying and evaluating some key issues of practices. First, value chain mapping helped to analyse the complex interactions between multi-actors. This information is critical to evaluate the general structure of the chain. Second, the mapping helped to distinguish the major actors who have the power to arrange the chain. Third, the mapping helped to identify the source of value creation. Finally, the mapping helped to identify constraints or bottlenecks of practices towards improvement. The empirical application in Indonesia's cashew sector had shown that there is a gap of practices between smallholders and other value chain actors in terms of governance and value addition. Although smallholders play an important role in supplying the global cashew market, they generally lack the capacity to fully participating in the export trade. Therefore, smallholders in Indonesia's cashew sectors should get greater attention from the key players and policymakers. There is an opportunity for smallholders to capture more value by practising value-added activities such as grading, processing, and certification at the smallholders' stage, along with other value chain players in Indonesia. It is also critical to develop the Producer Organisation (PO) at smallholders level to support their practices. Furthermore, the Government should help smallholders to increase not only economic but also social-environmental orientation in the area and the country, respectively.

Further investigation in broader sectors will be necessary to verify the findings due to the limitations of the current study scope. This study may not be able to generalize the overall cashew sector in Indonesia or in other developing countries. However, the outcomes of this study allow future follow-up research to establish a more explicit route into a value chain improvement. For instance, future research will necessarily address the maturity level of practices based on governance and value addition. Additionally, future research might also focus on how to transform a value chain to supply higher value markets. 


\section{References}

1. D. Kumar, P. Rajeev, IJEMS, 7, 1 (2016)

2. P. C. Ensign, J. Gen. Manag., 27, 1 (2001)

3. P. K. Mishra, K. Dey, J. Rural. Stud., 64 (2018)

4. DFID, JEL, December, Agricultural Development International, (2008)

5. E. B. Mc.Cullough, P. L. Pingali, K. G. Stamoulis, Eds., The Transformation of Agrifood Systems: Globalization, Supply Chains and Smallholder Farmers. Rome : London; (Sterling, VA: Food and Agriculture Organization of the United Nations ; Earthscan, 2008)

6. FAO, "Agrifood Market and Value Chains," in Rural Development Report, Accessed: Sep. 13, 2020. [Online]. Available: https://www.ifad.org/documents/30600024/ 30604603/chapter_6.pdf/8f07f4f9-6a91-496a-89c1-d1b120f8de8b (2012)

7. W. Bokelmann, M. E. Adamseged, "Contributing to a better understanding of the value chain framework in developing countries," p. 14, (2016)

8. P. K. Mishra, K. Dey, J. Rural. Stud., 64 (2018)

9. Rabobank, "Framework-for-an-Inclusive-Food-Strategy: Co-operatives - a Key for Smallholder Inclusion into Value Chains," Rabobank, (Utrecht/The Netherlands, 2012)

10. A. Royer, J. Bijman, V. Bitzer, Quality and innovation in food chains, no. 1. (Netherland: Wageningen Academic Publisher, 2016)

11. United Nations, World Economic and Social Survey 2013: Sustainable Development Challenges, (2013)

12. R. D. Norton, "Track 2 Methodology: Value Chain and Quality Criteria," in The Competitiveness of Tropical Agriculture, (2017)

13. R. Kaplinsky, M. Morris, A Handbook for Value Chain Research, no. September. (2000)

14. J. Thorpe, World Dev., 103 (2018)

15. R. Collins, Value Chain Management and Postharvest Handling. (Elsevier Inc., 2014)

16. A. R. Sjauw-Koen-Fa, V. Blok, S. W. F. Omta, IFAMR, 19, 1 (2016)

17. ILO/FAO/IFAD, "Agricultural Value Chain Development: Threat or Opportunity for Women's Employment?” p. 4, (2010)

18. ACi, A Value Chain Analysis of the Cashew Sector in Ghana. Technische Zusammenarbeit GmbH (GTZ), [Online]. Available: https://agoa.info/images/ documents/5130/Chashew_valuechain_analysis_Ghana.pdf (2010)

19. CBI, "Exporting Cashew Nuts to Europe." Ministry of Foreign Affair, (2016)

20. B. Dendena, S. Corsi, Agron. Sustain. Dev., 34, 4 (2014)

21. Ministry of Agriculture, "Tree Crop Estate Statistics Of Indonesia 2016-2018 : Cashew Nuts." Directorate General of Estate Crops, Ministry of Agriculture, (Dec. 2017). [Online]. Available: http://ditjenbun.pertanian.go.id/?publikasi=buku-publikasistatistik-2016-2018, (2017)

22. President Republic Indonesia Regulation, Presidential Regulation. (2016), p. 68. Accessed: Mar. 01, 2019. [Online]. Available: http://jdih.dephub.go.id/assets/ uudocs/perpres/2016/Perpres_44_tahun_2016_Daftar_Bidang_Usaha.pdf (2016)

23. R. Rosman, PSP, 17, 2 (2018)

24. E. B. Susanto, "Eksplorasi Tanaman Jambu Mete (Annacardium occidentale L.) Pada Beberapa Daerah Sentra Di Pulau Madura)," 6, p. 10, (2018)

25. F. Demang, S. Salengke, N. Brasit, IJEAB, 3, 1 (2018)

26. E. Fauziyah, A. Aniyatussholihah, D. R. Hidayati, Jejak, 10, 2, (2017)

27. N. Zahir, B. Sanawiri, JAB, 54, 1 (2018)

28. M. Christopher, Logistics \& Supply Chain Management, 4th ed., 48, 4 (Prentice Hall, 2011) 
29. R. Godfrey, Strategic Management: A Critical Introduction, 1st Eds. (London: Routledge, 2016)

30. P. Harmon, Business process Change: A Business process Management Guide for Managers and Process profesiionals. (Elsevier, 2014)

31. M. E. Porter, Competitive Advantage: Creating and Sustaining Superior Performance. (New York: The Free Press, 1985)

32. FAO, Developing Sustainable Food Value Chains: Guiding Principles. (Rome: Food and Agriculture Organization of The United Nations, 2014)

33. A. G. Chofreh, F. A. Goni, M. Zeinalnezhad, S. Navidar, H. Shayestehzadeh, J. J. Klemeš, J. Environ. Manag., 239 (2018)

34. K. Zokaei, Value Chain Analysis of the UK Food Sector. (Woodhead Publishing Limited, 2010)

35. G. Gereffi, J. Humphrey, and T. Sturgeon, Rev. Int. Polit. Econ., 12, 1 (2005)

36. J. Trienekens, M. van Velzen, N. Lees, C. Saunders, S. Pascucci, IFAMR, 21, 2 (2018)

37. P. M. van Dijk, J. Trienekens, Eds., Global Value Chains: Linking Local Producers from Developing Countries to International Markets. (Amsterdam: Amsterdam University Press, 2012)

38. D. Bochtis, C. A. G. Sørensen, D. Kateris, "Agriproducts Supply Chain Operations," in Operations Management in Agriculture, (Elsevier, 2019)

39. M. E. Cucagna, P. D. Goldsmith, IFAMR, (2018)

40. J. Humphrey, "Global Value Chains in The Agrifood Sector," (Vienna, 2006)

41. E. M. Berry, S. Dernini, B. Burlingame, A. Meybeck, P. Conforti, Public Health Nutr., 18, 3 (2015)

42. J. H. Trienekens, IFAMR, 14, 2 (2011)

43. Plantation Agency, "Strategic Plan of East Java Plantation Agency 2014-2019 (Rencana Strategis (RENSTRA) Dinas Perkebunan Provinsi Jawa Timur Tahun 2014 - 2019).” (East Java PLantation Agency, 2014)

44. J. M. Widjaya and G. Tanuwidjaja, IOP Conf. Ser.: Earth Environ. Sci., 79 (2017)

45. N. Jadid et al., "Traditional pattern of cashew cultivation: A lesson from SumenepMadura, Indonesia," Malang, Indonesia, (2017)

46. P. Childerhouse, D. R. Towill, Int. J. Prod. Res, 49, 24 (2011)

47. R. A. Hernández, J. M. Martínez Piva, N. Mulder, United Nations, Eds., Global Value Chains and World Trade: Prospects and Challenges for Latin America. Santiago, Chile: Economic Commission for Latin America and the Caribbean (ECLAC), (2014)

48. M. Boehlje, Am. J. Agric. Econ., 81, 5 (1999)

49. E. Garnevska, G. Liu, N. M. Shadbolt, IFAMR, 14, 4 (2011)

50. E. B. McCullough, P. L. Pingali, K. G. Stamoulis, The Transformation of Agri-Food Systems. (London: FAO and Earthscan, 2008)

51. S. Azevedo, M. Silva, J. Matias, G. Dias, Sustainability, 10, 6 (2018)

52. F. Monteiro, L. Catarino, D. Batista, B. Indjai, M. Duarte, M. Romeiras, Sustainability, 9, 9 (2017)

53. Norad, "Strengthening Practices in The Vietnamese Cashew Nut Industry: A Due Diligence Study on Labour Practices and Sustainability," Research Center for Employment Relations (ERC) and The Norwegian Agency for Development Cooperation (Norad), (2018) 